\title{
Geochemical evidence for seasonal variations in potential loess sources of the western Chinese Loess Plateau
}

\author{
Xunming Wang a, b, *, Lili Lang a, Hui Li ${ }^{\text {b }}$, Ting Hua ${ }^{\text {, }}$, Guangtao Wang ${ }^{\text {, }}$, Na Zhou ${ }^{\text {a }}$ \\ Linlin Jiao ${ }^{\text {a }}$ \\ a Key Laboratory of Water Cycle and Related Land Surface Processes, Institute of Geographic Sciences and Natural Resources Research, Chinese Academy of \\ Sciences, Beijing 100101, China \\ ${ }^{\mathrm{b}}$ Key Laboratory of Desert and Desertification, Cold and Arid Regions Environmental and Engineering Research Institute, Chinese Academy of Sciences, \\ Lanzhou 730000, China
}

\section{H I G H L I G H T S}

- Source of the loess deposited on the western Chinese Loess Plateau (CLP) varies.

- Dust-event frequency may not be an effective index for loess deposition rates.

- The link between particle size and geochemistry of loess source areas is complex.

- Both dry and wet deposition are equally important on the western CLP.

- Using loess-sequence geochemistry as a regional climate proxy should be appraised.

\section{A R T I C L E I N F O}

\section{Article history:}

Received 8 April 2015

Received in revised form 2 September 2015

Accepted 4 September 2015

Available online 8 September 2015

\section{Keywords:}

Loess

Source

Principal components analysis

Chinese Loess Plateau

\begin{abstract}
A B S T R A C T
This paper aims to characterize seasonal variations in the potential sources of loess deposited on the western Chinese Loess Plateau (CLP). Fallout was sampled every five days between March 2013 and August 2014 at Jiuzhoutai, the site with the largest loess deposits in northwest China. A total of 45 macro and trace elements, as well as rare earth elements, were analyzed in the samples. The results show that, at present, the potential sources of loess are mixed with pollutants. After exclusion of the pollutants, principal component analysis (PCA) showed significant seasonal variations in the potential loess sources on the western CLP. During the spring, summer-autumn, and winter periods, there are possibly six, four, and two potential loess sources, respectively, with crustal provenance at Jiuzhoutai. No significant differences in fallout amounts were found on the western CLP during periods with and without dust events, which suggests that the frequency of dust events may not be an effective index for deposition rates in areas of loess formation. The relatively high proportion of coarser material ( $>50 \mu \mathrm{m}$ in diameter) in the fallout indicates that at least part of the loess in the fallout samples originated from adjacent deserts and associated systems, and that both dry and wet deposition contributed equally to the fallout. Based on the significant seasonal and spatial variations in the loess sources, combined with variations in the link between the different particle size classes and the geochemical characteristics of potential components of the loess on the western CLP, the use of the geochemical characteristics of loess stratigraphic sequences as a proxy for regional paleoclimatic and environmental reconstructions should be carefully appraised.
\end{abstract}

() 2015 Elsevier Ltd. All rights reserved.

\section{Introduction}

Dust generated by the prevailing winds in arid, semiarid, and

* Corresponding author. Key Laboratory of Water Cycle and Related Land Surface Processes, Institute of Geographic Sciences and Natural Resources Research, Chinese Academy of Sciences, Beijing 100101, China

E-mail address: xunming@igsnrr.ac.cn (X. Wang). semi-humid areas of central Asia, which then accumulates via dry or wet deposition, is a potential source of the sediment that forms the Chinese Loess Plateau (CLP; Liu, 1985; Pye, 1987). The postdepositional effects of weathering (Liang et al., 2009) and pedogenesis (Zhang et al., 2012) generate variations in the composition of loess stratigraphic sequences, and these variations have been 
used as a proxy to reconstruct regional paleoclimates (Sun, 2005; Jeong et al., 2008; Sun et al., 2008; Hu et al., 2013; Wimpenny et al., 2014) and past atmospheric circulations (Gallet et al., 1996). In recent decades, many studies have suggested that the dominant sources of loess on the CLP are gobi and sandy deserts (Torii et al., 2001; Sun, 2002), deflation pans (Kapp et al., 2011), and piedmont alluvial fans (Derbyshire et al., 1998; Wang et al., 2008). Some have also suggested that the loess has multiple sources, and that before deposition these materials are mixed by changes in the local-to regional-scale atmospheric circulations (Kreutz and Sholkovitz, 2000). In addition to variations in loess sources, it has been suggested that the low wind velocity, low temperatures, and decreased precipitation during glacial periods (i.e., stages that are marked by colder temperatures and glacier advances) led to an increased frequency of dust events (Guan et al., 2013; Peng et al., 2014), and that this had a significant impact on the thickness of loess on the CLP (Porter, 2001; Vriend et al., 2011).

The great significance of the CLP loess stratigraphic sequences to paleoclimatic and environmental reconstructions has led to considerable interest in their potential source areas and composition (Lu and Sun, 2000; Lu et al., 2012). To date, most studies have focused on sediment sampled in the potential loess source regions, or used the composition of deposits in the loess stratigraphic sequences, to identify the source areas for the CLP. However, the amount of material supplied by the distinct loess sources may vary seasonally, and this may lead to uncertainties when attempting to determine potential loess sources and use them as an indicator of past environmental change. To improve our understanding of the characteristics of the potential loess sources, we collected fallout samples on the western CLP at five-day intervals between March 2013 and August 2014. The aim of this program was to fingerprint the possible loess sources, estimate the seasonal variations in the output from each source, and calculate the deposition rates of the loess accumulating on the western CLP. In addition, we appraised the seasonal variations in loess composition and considered their significance in order to facilitate the interpretation of paleoclimate records based on loess deposits.

\section{Collection site and analytical methods}

The sampling site was located at the summit of Jiuzhoutai $\left(35^{\circ} 58^{\prime} \mathrm{N}, 103^{\circ} 12^{\prime} \mathrm{E} ; 2066.8 \mathrm{~m}\right.$ above sea level), near Lanzhou City, northwest China (Fig. 1). Here, the mean annual wind velocity is $2.3 \mathrm{~m} / \mathrm{s}$ and the dominant wind direction is from the NW with no evident seasonal changes. The annual temperature, precipitation, and evaporation are $9.3^{\circ} \mathrm{C}, 329.7 \mathrm{~mm}$, and $1332.7 \mathrm{~mm}$, respectively. Loess began to accumulate at the site at about 1.4 Ma (e.g., Fang et al., 1997) and it is now $318.2 \mathrm{~m}$ thick. This is a representative site for the use of loess stratigraphic sequences to reconstruct paleoclimatic changes on the western CLP (Liu et al., 2009). The fallout was collected using trap fixed to the roof of a building with no shading within $100 \mathrm{~m}$, at a height of $>3 \mathrm{~m}$ above the ground surface. The fallout trap was a square glass vessel that was $50 \mathrm{~cm}$ long and $100 \mathrm{~cm}$ high. Field testing showed that after capture no fallout escaped from the vessel, even when wind speeds exceeded $3 \mathrm{~m} / \mathrm{s}$, which is relatively high for this site. Every five days, the samples within the trap were transferred into plastic bags for analysis, and then the vessel was washed with demineralized distilled water prior to further sample collection. During the rainy season, the collection interval was sometimes extended to 6-10 days until the samples were spontaneously dried. A total of 62 samples were collected between March 2013 and August 2014.

The samples were weighed prior to analysis by ICP-MS (Elan DRC-e, PE, USA) and ICP-OES (Optima 5300DV, PE, USA) at the Institute of Geographic Sciences and Natural Resources Research, Chinese Academy of Sciences, China. First, $0.05 \mathrm{~g}$ subsamples were dissolved in ultrapure solutions of $\mathrm{HNO}_{3}(3 \mathrm{ml}), \mathrm{HF}(3 \mathrm{ml})$, and $\mathrm{HClO}_{4}(1 \mathrm{ml})$, and heated in Teflon crucibles at $120{ }^{\circ} \mathrm{C}$ for 30-45 min and then at $180{ }^{\circ} \mathrm{C}$ for about $6 \mathrm{~h}$. After the solutions were dried, $1 \mathrm{ml} \mathrm{HF}, 1 \mathrm{ml} \mathrm{HNO}_{3}$, and $0.1 \mathrm{ml} \mathrm{HClO}_{4}$ were added to the samples and they were then heated again for 7-10 h. These procedures were repeated until no solid particles remained in the solutions. After the solutions were cooled, $3 \mathrm{ml}$ aliquots were extracted with a plate and then heated until the solutions reached boiling point. After the samples cooled again, they were diluted with ultrapure water and made up to $25 \mathrm{ml}$ solutions, and the concentration of trace elements, REEs, and macro-elements in the samples was then determined.

The Chinese National Reference Materials GSS-8 (loess sediments sampled in Luochuan, CLP) and GSD-6 (river sediments sampled in Zhaduo, Qinghai) were used to monitor the accuracy of the analytical procedures (see Wu et al., 2009). Repeated

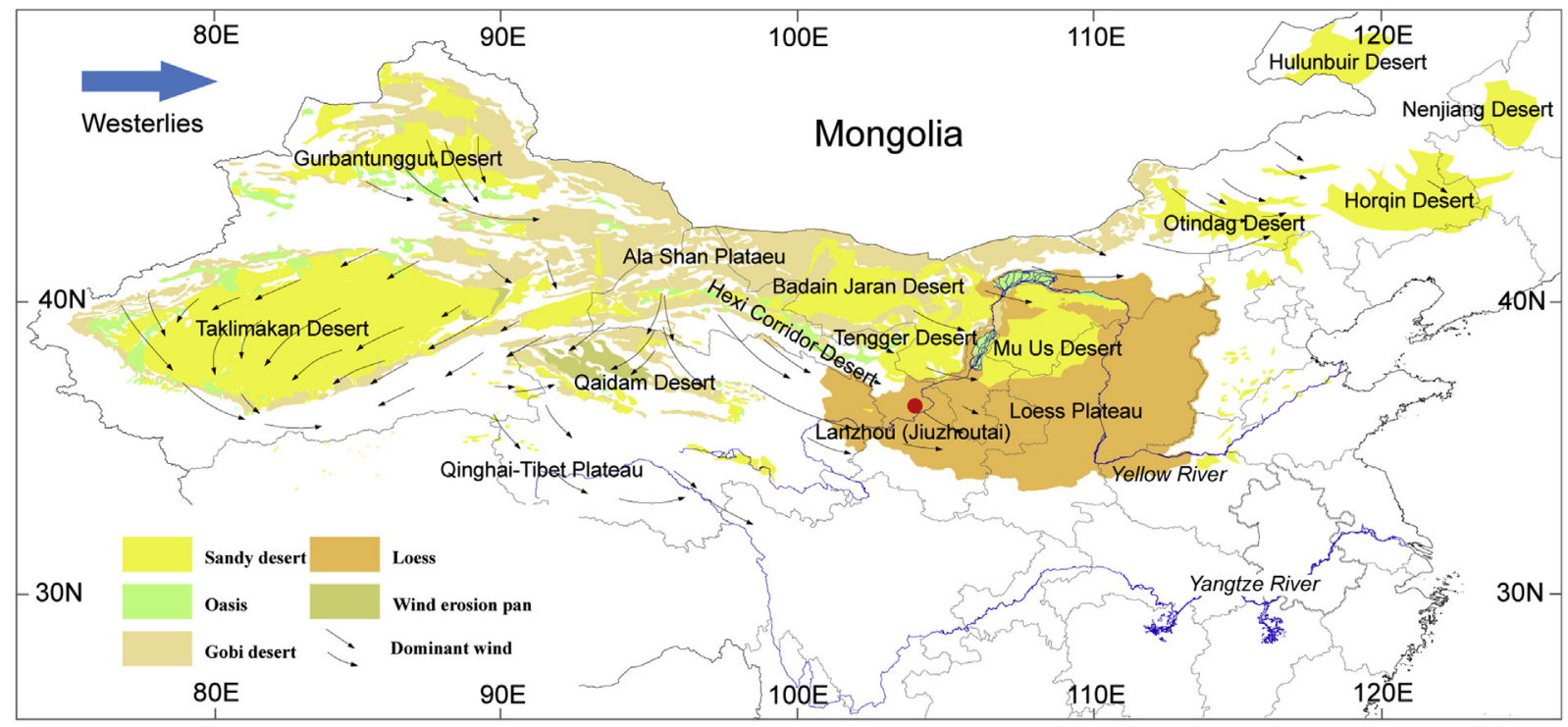

Fig. 1. Map showing loess distribution in China and the location of the sampling site. 
measurements of GSS-8 and GSD-6 showed that the measurement accuracy was $\pm 15 \%$ and $\pm 10 \%$ (relative standard deviations), respectively, for most elements. The background values of a laboratory blank were also measured, and after all sample measurements were completed, the blank background values were subtracted to calculate the actual values of the element contents within the samples. In total, the content and temporal variations of 45 elements were measured: $\mathrm{Al}, \mathrm{Ba}, \mathrm{Be}, \mathrm{Bi}, \mathrm{Ca}, \mathrm{Cd}, \mathrm{Ce}, \mathrm{Co}, \mathrm{Cr}, \mathrm{Cs}, \mathrm{Cu}$, $\mathrm{Dy}, \mathrm{Er}, \mathrm{Eu}, \mathrm{Fe}, \mathrm{Ga}, \mathrm{Gd}, \mathrm{Ho}$, In, K, La, Li, Lu, Mg, Mn, Mo, Na, ${ }^{142} \mathrm{Nd}$, ${ }^{143} \mathrm{Nd}, \mathrm{Ni}, \mathrm{P}, \mathrm{Pb}, \mathrm{Pr}, \mathrm{Rb}, \mathrm{Sc}, \mathrm{Sm}, \mathrm{Tb}, \mathrm{Ti}, \mathrm{Tl}, \mathrm{Tm}, \mathrm{U}, \mathrm{V}, \mathrm{Y}, \mathrm{Yb}$, and Zn. Prior to particle size analysis using a Mastersizer 2000 (Malvern Co. Ltd, Malvern, UK; measurement range: $0.02-2000 \mu \mathrm{m})$, the samples were immersed in $10 \% \mathrm{H}_{2} \mathrm{O}_{2}$ and then $12.7 \% \mathrm{HCl}$ to remove any organic material.

\section{Results and discussion}

\subsection{Seasonal variations in fallout amounts}

Between March 2013 and August 2014, the mean fallout amount at the sampling site was $1.56 \mathrm{~g} \mathrm{~m}^{-2} \mathrm{day}^{-1}$, with a maximum of 7.06 and a minimum of $0.07 \mathrm{~g} \mathrm{~m}^{-2} \mathrm{day}^{-1}$ (Fig. 2). The highest amounts of fallout usually occurred between March and October, and there were relatively lower fallout amounts in winter. During the collection period, about 10 dust events (with visibility $<10 \mathrm{~km}$ ) occurred in this region, but periods of high fallout did not always coincide with these events, which suggests that the frequency of dust events may not be an effective indicator of deposition rates on the western CLP. In addition, there was no consistent relationship between days with low wind velocity or rainfall, and fallout amounts, which indicates that both dry and wet deposition play key roles in controlling the intensity of fallout at this site.

\subsection{Seasonal variations in fallout particle size}

Seasonal variations in the particle size of the fallout are shown in Fig. 3. During the collection periods, the median and mean particle sizes of the fallout were 23 and $25 \mu \mathrm{m}$, respectively, and the mean contents of PM 2.5 (particle size $<2.5 \mu \mathrm{m}$ in diameter), PM 5 , PM 10, PM 50, and the fraction $>50 \mu \mathrm{m}$ were $8.0 \%, 15.5 \%, 27.8 \%$, $83.5 \%$, and $16.5 \%$, respectively. On the western CLP, the dominant fractions of the loess are those in the $<63 \mu \mathrm{m}$ range, and especially the $<50 \mu \mathrm{m}$ fraction (Liu, 1985), and the relatively high proportion of coarse particles shows that these fractions may be generated from local sources or be transported only a short distance and then deposited in the region (Pye, 1995). There were no consistent relationships between the different size fractions of the fallout and the occurrence of dust events, rainfall, or variations in wind velocity, which suggests that the occurrence (or otherwise) of dust events, and the nature of the deposition process (dry or wet), have no significant effect on the particle size distribution of the fallout. In addition, our results show no significant seasonal variations in the particle size distributions of the fallout (Fig. 3) on the western CLP.

\subsection{Seasonal variations in the chemical composition of fallout and relationship with particle size}

There were significant temporal variations in the chemical composition of the fallout collected during the sampling period. Certain macro-elements, such as $\mathrm{Fe}, \mathrm{Al}, \mathrm{K}, \mathrm{Na}, \mathrm{Ba}, \mathrm{Mn}, \mathrm{V}$, and $\mathrm{Ti}$, had a coefficient of variation (CV) of $<20 \%$, and for REEs such as Tb, Dy, $\mathrm{Ho}, \mathrm{Er}, \mathrm{Tm}, \mathrm{Yb}, \mathrm{Lu}$, and Ga the CV was $<15 \%$. However, for some

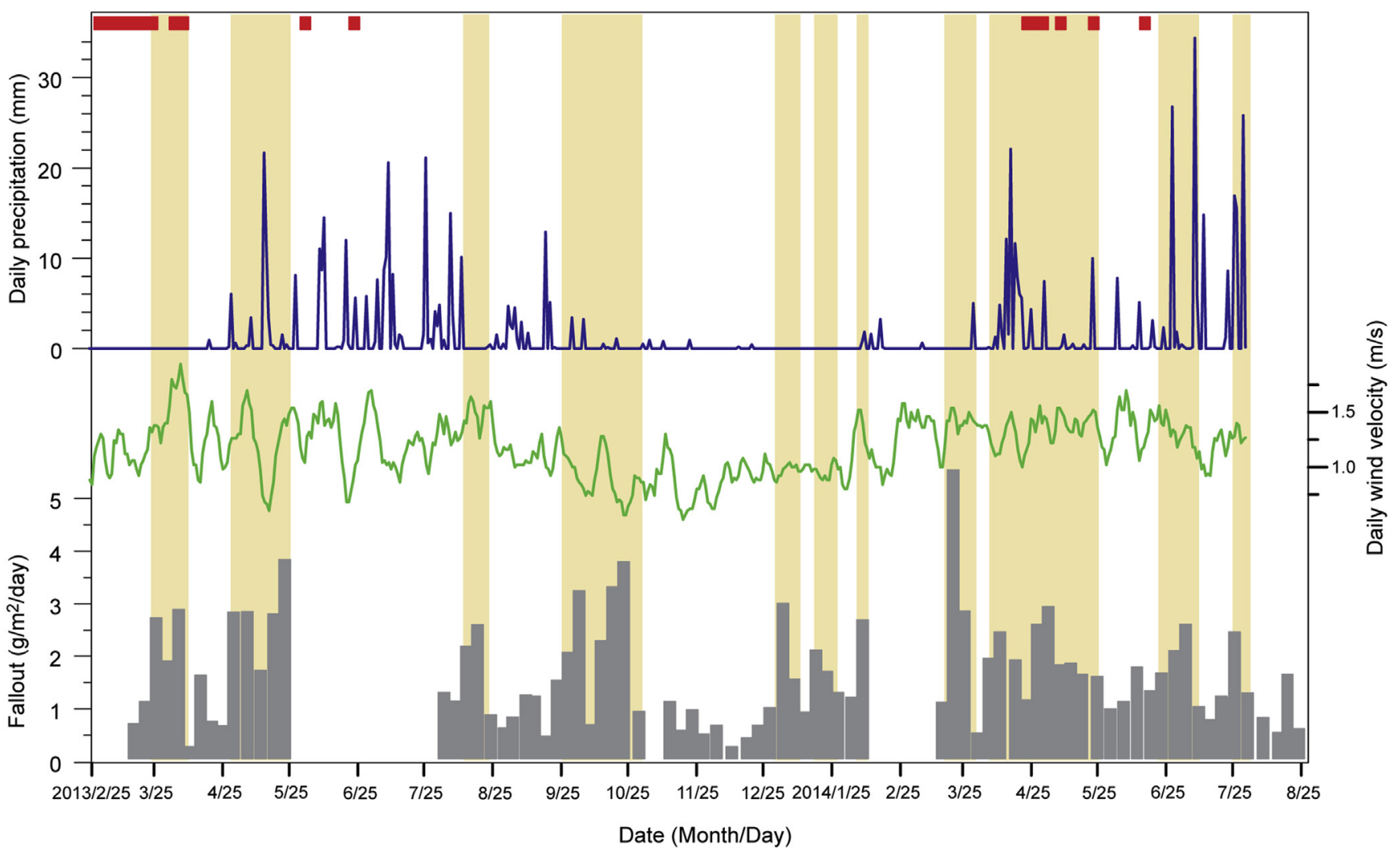

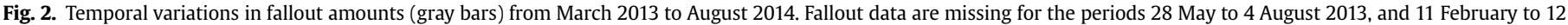
March 2014. The red bars indicate dust storm events, and the yellow shading indicates periods of relatively high fallout. 

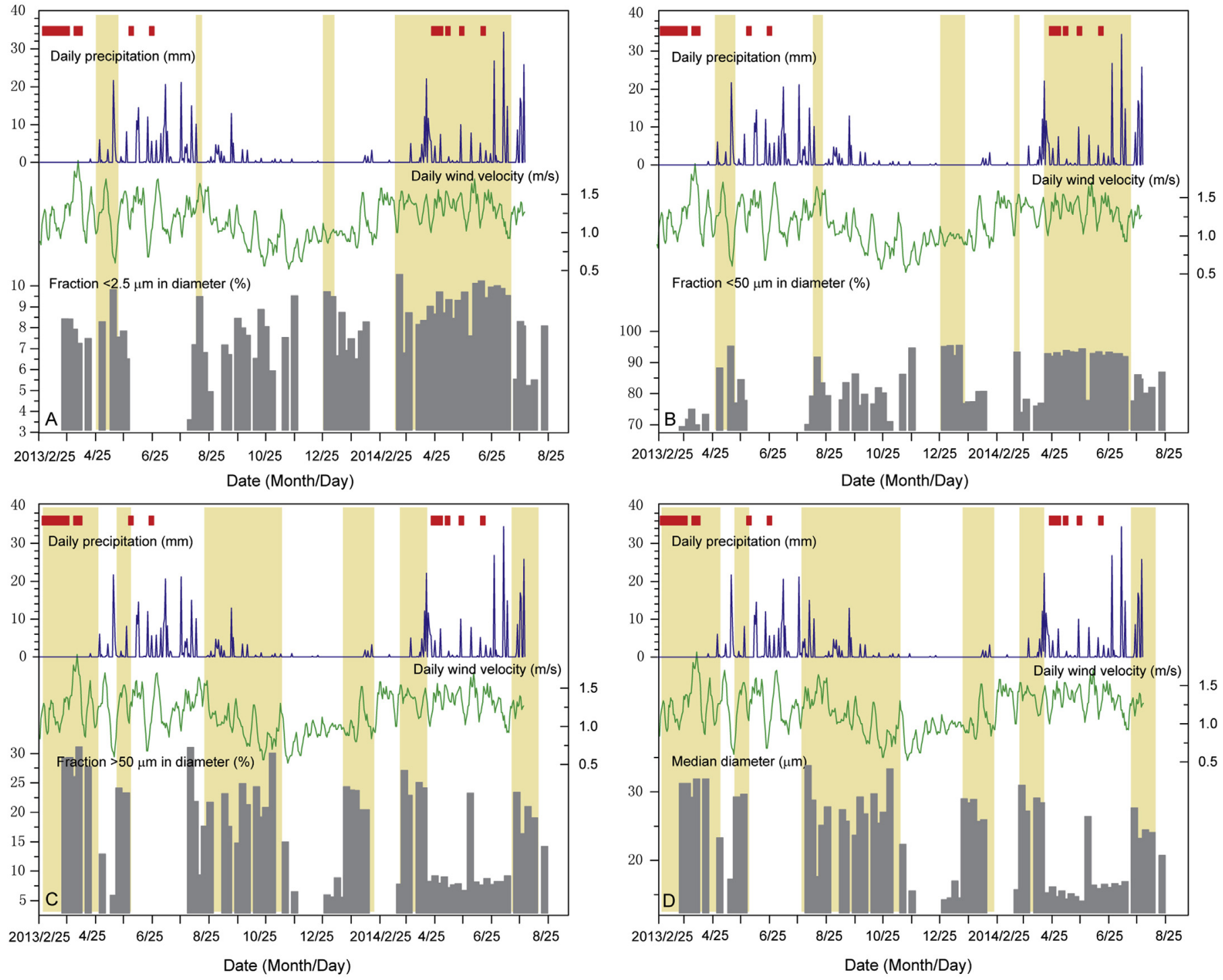

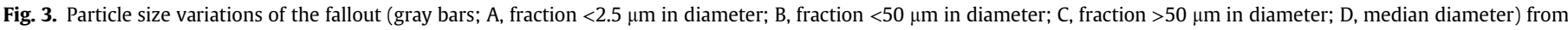
March 2013 to August 2014. The yellow shading indicates periods with relatively high proportions of different particle sizes.

elements, such as $\mathrm{Zn}, \mathrm{Cu}, \mathrm{Pb}, \mathrm{Co}, \mathrm{Ti}, \mathrm{In}, \mathrm{Bi}$, and $\mathrm{Mo}$, the $\mathrm{CV}$ was typically $>30 \%$, and for $\mathrm{Cd}$ it was almost $80 \%$ (Table 1 ). These results indicate that fallout containing low-CV elements had consistent sources, whereas the higher-CV elements such as $\mathrm{Cd}, \mathrm{Pb}$, and Mo

Table 1

Coefficients of variation (CV) of the elements/oxides measured.

\begin{tabular}{llllllll}
\hline $\mathrm{Al}_{2} \mathrm{O}_{3}$ & $\mathrm{CaO}$ & $\mathrm{Fe}_{2} \mathrm{O}_{3}$ & $\mathrm{~K}_{2} \mathrm{O}$ & $\mathrm{MgO}$ & $\mathrm{Na}_{2} \mathrm{O}$ & $\mathrm{Ba}$ & $\mathrm{La}$ \\
10.57 & 24.15 & 12.52 & 9.75 & 27.66 & 18.15 & 11.02 & 27.60 \\
$\mathrm{Mn}$ & $\mathrm{Ni}$ & $\mathrm{P}$ & $\mathrm{Sc}$ & $\mathrm{Sr}$ & $\mathrm{V}$ & $\mathrm{Ti}$ & $\mathrm{Zn}$ \\
10.69 & 21.26 & 11.95 & 22.17 & 14.13 & 11.83 & 10.20 & 51.69 \\
$\mathrm{Cu}$ & $\mathrm{Li}$ & $\mathrm{Pb}$ & $\mathrm{Cr}$ & $\mathrm{Cd}$ & $\mathrm{Co}$ & $\mathrm{Tl}$ & $\mathrm{Cs}$ \\
62.00 & 14.52 & 67.16 & 19.96 & 78.62 & 31.97 & 43.99 & 13.99 \\
$\mathrm{Ga}$ & $\mathrm{In}$ & $\mathrm{Rb}$ & $\mathrm{U}$ & $\mathrm{Bi}$ & $\mathrm{Mo}$ & $\mathrm{Be}$ & $\mathrm{Y}$ \\
16.36 & 48.88 & 9.87 & 9.92 & 61.83 & 34.17 & 20.44 & 11.56 \\
$\mathrm{La}$ & $\mathrm{Ce}$ & $\mathrm{Pr}$ & $142 \mathrm{Nd}$ & $143 \mathrm{Nd}$ & $\mathrm{Sm}$ & $\mathrm{Eu}$ & $\mathrm{Gd}$ \\
21.74 & 10.87 & 11.30 & 21.15 & 11.77 & 10.59 & 10.68 & 10.14 \\
$\mathrm{~Tb}$ & $\mathrm{Dy}$ & $\mathrm{Ho}$ & $\mathrm{Er}$ & $\mathrm{Tm}$ & $\mathrm{Yb}$ & $\mathrm{Lu}$ & \\
10.07 & 10.12 & 10.07 & 9.71 & 10.06 & 9.53 & 10.00 & \\
\hline
\end{tabular}

suggest significant seasonal variations in their sources.

In addition, there were no regular patterns in the seasonal trends of element content (Fig. 4). For instance, during the sampling period, higher amounts of $\mathrm{Fe}_{2} \mathrm{O}_{3}$ were recorded in November and December, which is inconsistent with the occurrence of dust storms. For other elements, such as Tm and Eu, high values were also recorded in periods both with and without dust events. For $\mathrm{Cd}$, the highest amounts usually occurred in periods with no dust events, which indicates that most of the fallout containing this element did not have a crustal provenance. Particle size analysis showed that although most elements had positive correlations with the fine fraction, there were also variations in the correlation of the fine fraction with different particle size classes (Table S1). For instance, $\mathrm{CaO}$ and $\mathrm{MgO}$ have relatively high correlations with the PM 2.5 fraction; $\mathrm{Fe}_{2} \mathrm{O}_{3}, \mathrm{~V}, \mathrm{Li}, \mathrm{Cr}, \mathrm{Cs}, \mathrm{U}, \mathrm{Pr}$, and ${ }^{142} \mathrm{Nd}$ have higher correlations with the PM 10 fraction; La, Ni, Zn, Pb, Cd, Co, Ti, In, Bi, and Mo are more positively correlated with the PM 50 fraction; $\mathrm{K}_{2} \mathrm{O}$ has a significant positive correlation with the coarse fraction ( $>50 \mu \mathrm{m}$ in diameter); and $\mathrm{Na}_{2} \mathrm{O}, \mathrm{Ba}, \mathrm{Mn}, \mathrm{P}, \mathrm{Sc}, \mathrm{Sr}, \mathrm{Ti}, \mathrm{Cu}, \mathrm{Ga}, \mathrm{Rb}, \mathrm{Be}$, $\mathrm{Y}, \mathrm{Ce},{ }^{143} \mathrm{Nd}, \mathrm{Sm}, \mathrm{Eu}, \mathrm{Gd}, \mathrm{Tb}, \mathrm{Dy}, \mathrm{Ho}, \mathrm{Er}, \mathrm{Tm}, \mathrm{Yb}$, and Lu have no 

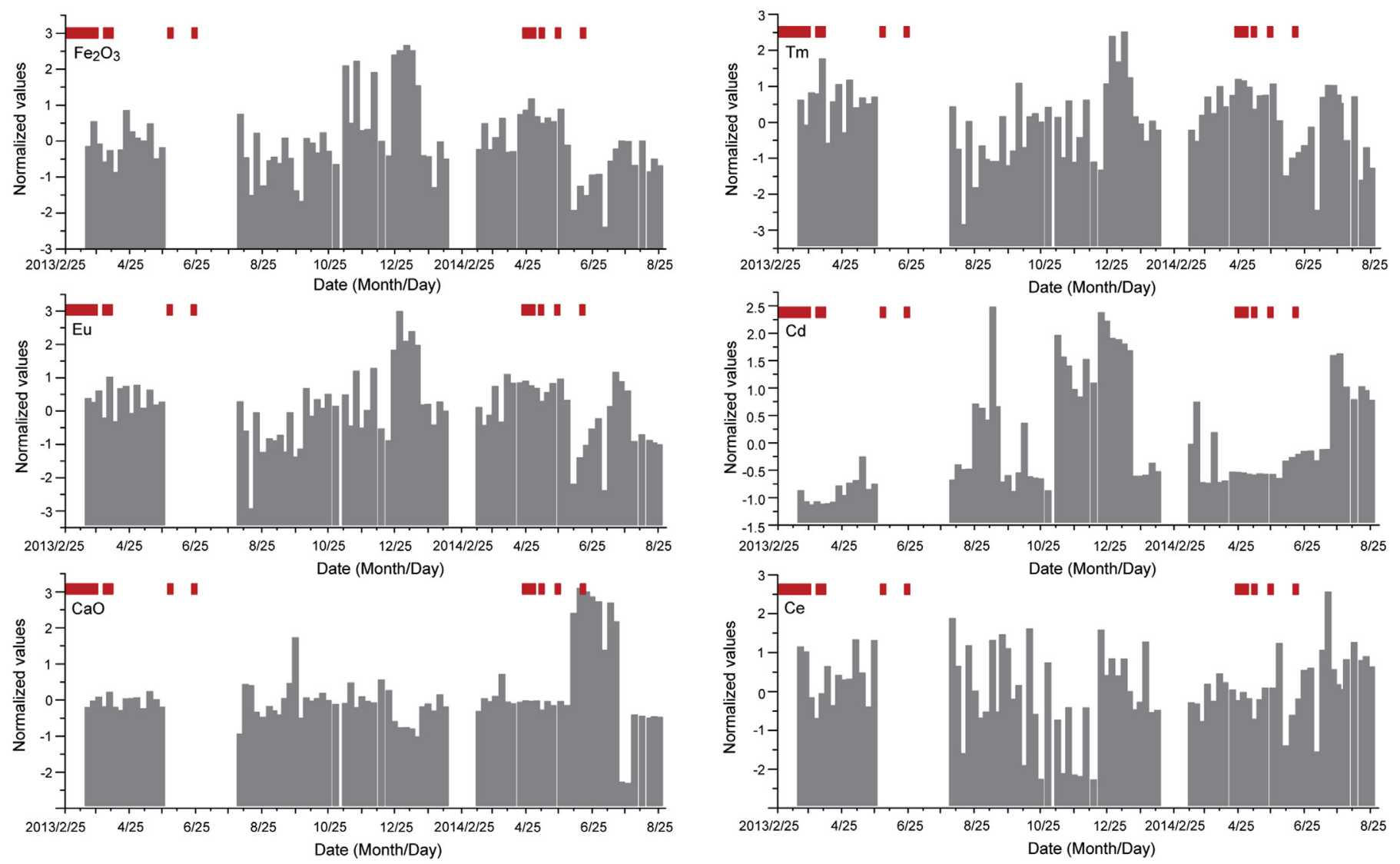

Fig. 4. Variations in selected element concentrations in the fallout (gray bars) from March 2013 to August 2014.

significant correlations with the particle size characteristics of the fallout. The variation in the relationship between the different particle size classes and the geochemical characteristics of the potential loess compositions shows that the use of the changing chemical and physical properties of loess stratigraphic sequences as proxies in paleoclimatic and other environmental reconstructions should be reappraised.

\subsection{Significances of variations in amount and geochemical characteristics of fallout}

An international convention states that a dust event is defined by visibility of $<10 \mathrm{~km}$ (CCMB, 1979), and the frequency of dust events is typically used as an index of the intensity of emissions from dust source areas (e.g., Sun et al., 2000, 2001; Qian et al., 2002; Zhou and Zhang, 2003; Wang et al., 2004, 2005, 2006, 2008). However, in the areas where the dust is deposited, such as the western CLP, the dust emitted from the source areas settles by both dry and wet deposition, and the present results show that the frequency of dust occurrence may not be an effective indicator of the intensity of fallout in the region.

Although previous studies suggested that dry deposition is the dominant process of fallout on the CLP because of low wind velocities (Liu, 1985; Pye, 1987), the sampling of fallout in this study indicates that wet deposition plays an equivalent role in fallout settlement in the region. For instance, the averaged fallout amount within the rainy seasons (27 April to 20 September 2013 and 20 April to 26 July 2014) was $1.63 \mathrm{~m}^{-2}$ day $^{-1}$, compared with $1.51 \mathrm{~m}^{-2} \mathrm{day}^{-1}$ in the dry seasons. In addition, several factors may result in high fallout amounts on the western CLP that are not always related to periods with dust events. First, after dust is emitted from the source areas and transported downwind, most particles, and especially fine particles, may be suspended in the upper atmosphere for long periods and so may settle during the periods between dust events (Pye, 1995). Second, before settling, some particles sourced far from the CLP (e.g., the western regions of central Asia) and transported by the westerly wind (Fang et al., 1999) may lag the settlement of these materials on the CLP. Finally, pollutants generated by local sources may result in high fallout amounts. For instance, previous studies have confirmed that at global and regional scales, modern pollutants are already a serious issue, and may also be significant contributors to fallout amounts during periods with no dust events (e.g., Knutsen et al., 2004; Maher et al., 2008).

At the present sample site, previous studies have found that the pollutants are mainly $\mathrm{Zn}, \mathrm{Cd}, \mathrm{Cr}, \mathrm{Cu}, \mathrm{As}, \mathrm{Pb}, \mathrm{Sb}, \mathrm{Se}$, and $\mathrm{Mo}$ (e.g., Xiao et al., 2010, 2013, 2014; Zhang et al., 2011; Lin et al., 2012; Wang et al., 2012, 2013), and this was confirmed in the present study by the principal component analysis (PCA) of the elements in the fallout. For instance, for all samples collected, the PCA results show that six principal components (PCs) were extracted (Table S2). Among these PCs, PC 1 explained 51.2\% of the variance, and PC 2 to PC 6 explained $18.1 \%, 8.1 \%, 4.5 \%, 4.07 \%$, and $2.8 \%$ of the variance, respectively. Most of the elements $\left(\mathrm{Al}_{2} \mathrm{O}_{3}, \mathrm{Fe}_{2} \mathrm{O}_{3}, \mathrm{~K} 2 \mathrm{O}, \mathrm{Ba}, \mathrm{Mn}, \mathrm{Ni}, \mathrm{P}\right.$, Sc, V, Ti, Li, Cr, Co, Cs, Ga, Rb, U, Be, Y, Pr, ${ }^{143} \mathrm{Nd}, \mathrm{Sm}, \mathrm{Eu}, \mathrm{Gd}, \mathrm{Tb}, \mathrm{Dy}$, $\mathrm{Ho}, \mathrm{Er}, \mathrm{Tm}, \mathrm{Yb}$, and Lu) are included in PC 1, which suggests that most of the fallout that contains these elements has a crustal provenance. PC 2 contained $\mathrm{La}, \mathrm{Zn}, \mathrm{Cu}, \mathrm{Pb}, \mathrm{Cd}, \mathrm{Tl}, \mathrm{In}, \mathrm{Bi}$, and $\mathrm{Mo}$, and taking the results of previous studies on pollutant compositions in this region into account, we infer that the fallout containing these 
elements was generated from local pollutants. PC 3 includes Ca and $\mathrm{Mg}$, and these components may also be generated from local sources because the surface soils in this region are enriched in $\mathrm{Ca}$ (Gong et al., 2014). PC 4 and PC 5 include Ce, Na, and Ba; however, based on the current data, we cannot fingerprint their original sources.

Regardless of the seasonal variations, the dominant sources of loess on the CLP remain to be clarified. For instance, based on element analysis, although some studies (e.g., Guan et al., 2008) have suggested that the piedmont alluvial fan of the Qilian Mountains is the direct source of dust material for the CLP (given the absence of samples with seasonal scales), there may be other loess sources. The Qaidam Basin and the northern Tibetan Plateau are thought to be potential sources for the CLP because of the high wind erosion that occurred during the stadial periods and the westerly wind patterns (Kapp et al., 2011; Pullen et al., 2011). However, our analysis shows that high fallout amounts may occur in all seasons, which further indicates that huge loess deposition may have occurred during both glacial and interglacial stages, and been generated from multiple sources. In addition, particle size analysis and previous studies indicate that the coarse fractions of the fallout at the present sample site were not generated from local sources because local surface soils are enriched in fine calcium carbonates (CNEMC, 1990). The current data do not reveal whether the thick loess stratigraphic sequences on the CLP were generated from the Mu Us, Tengger, and Badain Jaran sandy deserts (Amit et al., 2014), although the high proportion of coarse fractions within the fallout shows that at least part of the loess at the site was derived from adjacent deserts, the nearby Yellow River, and associated systems (Stevens et al., 2013a,b), and was only transported a short distance before being deposited.

The significant seasonal and spatial variations in the composition of the fallout show that the loess deposited on the CLP is derived from multiple (Sun et al., 2008) and mixed (Zhang et al., 2012) sources. Based on our preliminary PCA results, the elements that are derived mainly from pollutants, such as $\mathrm{La}, \mathrm{Zn}, \mathrm{Cu}$, $\mathrm{Pb}, \mathrm{Cd}, \mathrm{Tl}, \mathrm{In}, \mathrm{Bi}$, and $\mathrm{Mo}$, were excluded from analysis and the elements derived from crustal materials were analyzed further. Our results show that although all elements are included in PC 1 , three PCs can still be extracted. PC 1 explained $67.9 \%$ of the variance, whereas PC 2 and PC 3 explained 10.1\% and 6.0\% of the variance, respectively (Table S3a), which indicates at least three sources for the fallout collected in the region. In addition, there were variations in the potential sources of the fallout in different seasons. During spring, six PCs explained $87.7 \%$ of the variance, and PC 1 to PC 6 explained $44.0 \%, 20.8 \%, 10.5 \%, 5.1 \%, 4.0 \%$, and $3.4 \%$ of the variance, respectively, which shows that in spring there were at least six potential sources of loess (Table S3b). In summer and autumn, four PCs explained $86.7 \%$ of the variance, and PC 1 to PC 4 explained $61.0 \%, 14.7 \%, 7.3 \%$, and $3.8 \%$, respectively, which shows that in summer and autumn there were at least four potential loess sources (Table S3c). In winter, only two PCs were extracted from the PCA results and they explained $82.3 \%$ and $9.8 \%$ of the variance, which indicates only two potential loess sources in this season (Table S3d).

Most of the REEs in the fallout and loess are derived from crustal material and have already been identified in previous studies (e.g., Jahn et al., 2001; Yang et al., 2007; Wang et al., 2009). Based on the second round of PCA results above, all macro-elements were also excluded from further analysis and only the REEs Sm, Eu, Gd, Tb, Dy, $\mathrm{Ho}, \mathrm{Er}, \mathrm{Tm}, \mathrm{Yb}$, and Lu were considered. The results show that although all REEs were included in PC 1 (Table S4a), there were still some seasonal differences in the PCs, which indicates seasonal variations in the potential loess sources with a crustal provenance. For instance, considering all of the samples, although only one PC could be extracted there were two PCs that explained $>1 \%$ of the variance, which shows that during the sampling period there were at least two potential sources of crustal material. In addition, for spring, summer-autumn, and winter, we found that five, two, and two PCs explained $>1 \%$ of the variance, respectively, indicating that significant seasonal variations existed in potential sources of loess with a crustal provenance (Table S4b-d), despite there being only one dominant potential source at the site. Therefore, although the identical loess sources cannot be identified based solely on the current analysis, there are significant seasonal variations in the potential sources of the loess deposited on the western CLP. Given the multiple and wide seasonal variations in loess sources, their significance as proxies for past climate reconstruction must be carefully reappraised.

\section{Conclusions}

Samples of fallout collected on the western CLP between March 2013 and August 2014 showed no significant differences in the fallout amounts between periods with and without dust events, which suggests that the occurrence frequency of such dust events may not be an effective index for the intensity of deposition in areas of loess formation. Although fallout is dominated by the fine fraction $(<50 \mu \mathrm{m}$ in diameter), the relatively large amounts of coarser material $(>50 \mu \mathrm{m}$ in diameter) show that one of the sources of the loess accumulating at the sampling site is adjacent deserts and associated systems. We also found that dry and wet deposition contribute equally to the fallout of dust on the western CLP. PCA results revealed significant seasonal variations in the potential loess sources on the western CLP. At our sampling site, we identified six, four, and two potential loess sources with a crustal provenance in spring, summer-autumn, and winter, respectively. Significant seasonal and spatial variations in the loess sources, combined with variations in the links between the different particle size classes and the geochemical characteristics of the potential loess compositions, suggest that using the geochemical characteristics of loess stratigraphic sequences as proxies in regional paleoclimatic and environmental reconstructions should be carefully appraised.

\section{Acknowledgments}

This work was supported by a grant from the National Natural Science Foundation of China (41225001) and by the Foundation of the Director of the Institute of Geographic Sciences and Natural Resources Research, Chinese Academy of Sciences. Special thanks are given to the anonymous referees and the Editor for their constructive criticism of this manuscript.

\section{Appendix A. Supplementary data}

Supplementary data related to this article can be found at http:// dx.doi.org/10.1016/j.atmosenv.2015.09.009.

\section{References}

Amit, R., Enzel, Y., Mushkin, A., Gillespie, A., Batbaatar, J., Crouvi, O., Vandenberghe, J., An, Z., 2014. Linking coarse silt production in Asian sand deserts and Quaternary accretion of the Chinese Loess Plateau. Geology 42, 23-26.

China Central Meteorological Bureau (CCMB), 1979. Standards on Weather Observation. Meteorological Press, Beijing, pp. 1-22 (in Chinese)

China National Environmental Monitoring Centre (CNEMC), 1990. Environmental Background Values of Soils in China. China Environmental Science Press, Beijing, p. 501 (in Chinese).

Derbyshire, E., Meng, X., Kemp, R.A., 1998. Provenance, transport and characteristics of modern aeolian dust in western Gansu Province, China, and interpretation of the Quaternary loess record. J. Arid Environ. 39, 497-516.

Fang, X., Li, J., der Voo, R.V., Niocaill, C.M., Dai, X., Kemp, R.A., Derbyshire, E., Cao, J., 
Wang, J., Wang, G., 1997. A record of the Blake Event during the last interglacial paleosol in the western Loess Plateau of China. Earth Planet. Sci. Lett. 146, 73-82.

Fang, X., Ono, Y., Fukusawa, H., Pan, B., Li, J., Guan, D., Qi, K., Tsukamoto, S., Torii, M. Mishima, T., 1999. Asian summer monsoon instability during the past 60,000 years: magnetic susceptibility and pedogenic evidence from the western Chinese Loess Plateau. Earth Planet. Sci. Lett. 168, 219-232.

Gallet, S., Jahn, B., Torii, M., 1996. Geochemical characterization of the Luochuan loess-paleosol sequence, China, and paleoclimatic implications. Chem. Geol. 133, 67-88.

Gong, Z., Huang, R., Zhang, G., 2014. Soil Geography of China. Science Press, Beijing, p. 636 (in Chinese).

Guan, Q., Pan, B., Gao, H., Li, N., Zhang, H., Wang, J., 2008. Geochemical evidence of the Chinese loess provenance during the Late Pleistocene. Palaeogeogr. Palaeoclimatol. Palaeoecol. 270, 53-58.

Guan, Q., Pan, B., Yang, J., Wang, L., Zhao, S., Gui, H., 2013. The processes and mechanisms of severe sandstorm development in the eastern Hexi Corridor China, during the Last Glacial period. J. Asian Earth Sci. 62, 769-775.

Hu, P., Liu, Q., Torrent, J., Barrón, V., Jin, C., 2013. Characterizing and quantifying iron oxides in Chinese loess/paleosols: implications for pedogenesis. Earth Planet. Sci. Lett. 369-370, 271-283.

Jahn, B., Gallet, S., Han, J., 2001. Geochemistry of the Xining, Xifeng and Jixian sections, Loess Plateau of China: eolian dust provenance and paleosol evolution during the last $140 \mathrm{ka}$. Chem. Geol. 178, 71-94.

Jeong, G.Y., Hillier, S., Kemp, R.A., 2008. Quantitative bulk and single-particle mineralogy of a thick Chinese loess-paleosol section: implications for loess provenance and weathering. Quat. Sci. Rev. 27, 1271-1287.

Kapp, P., Pelletier, J.D., Rohrmann, A., Heermance, R., Russell, J., Ding, L., 2011. Wind erosion in the Qaidam basin, central Asia: implications for tectonics, paleoclimate, and the source of the Loess Plateau. GSA Today 21. http://dx.doi.org 10.1130/GSATG99A.1.

Knutsen, S., Shavlik, D., Chen, L.H., Beeson, W.L., Ghamsary, M., Petersen, F., 2004 The association between ambient particulate air pollution levels and risk of cardiopulmonary and all-cause mortality during 22 years follow-up of a nonsmoking cohort. Results from the AHSMOG study. Epidemiology 15 (4). ISEE-81.

Kreutz, K.J., Sholkovitz, E.R., 2000. Major element, rare earth element, and sulfur isotopic composition of a high-elevation firn core: sources and transport of mineral dust in central Asia. Geochem. Geophys. Geosyst. 1. Paper No. 2000GC000082.

Liang, M., Guo, Z., Kahmann, A.J., Oldfield, F., 2009. Geochemical characteristics of the Miocene eolian deposits in China: their provenance and climate implications. Geochem. Geophys. Geosyst. 10, Q04004. http://dx.doi.org/10.1029/ 2008GC002331.

Lin, H., Wu, X., Zhang, J., Lu, W., Zhang, Y., Wang, S., Xie, M., Liu, Z., 2012. Analysis of atmospheric particles and heavy metals character at the area of Lanzhou City in summer and winter. China Environ. Sci. 32, 810-815 (in Chinese).

Liu, T., 1985. Loess and Environments. China Ocean Press, Beijing, p. 251 (in Chinese).

Liu, X., Mao, X., Ding, Z., Lv, B., Guo, X., Chen, Q., Chen, J., Jia, J., Yang, S., Paul, H., Chen, F., 2009. Study on the relation between loess paleoclimate trend and uplift Tibetan Plateau. Quat. Sci. 29, 988-999 (in Chinese).

Lu, H., Sun, D., 2000. Pathways of dust input to the Chinese Loess Plateau during the last glacial-interglacial periods. CATENA 40, 251-261.

Lu, H., Wang, X., Wang, X., Sun, X., Yi, S., Zhou, Y., Liu, Q., Swinehart, J., Vandenberghe, J., 2012. Palaeoclimatic changes in northeastern Qinghai-Tibetan Plateau revealed by magnetostratigraphy and magnetic susceptibility analysis of thick loess deposits. Neth. J. Geosci. Geol. Mijnb. 91, 189-198.

Maher, B.A., Moore, C., Matzka, J., 2008. Spatial variation in vehicle-derived metal pollution identified by magnetic and elemental analysis of roadside tree leaves. Atmos. Environ. 42, 364-373.

Peng, S., Ge, J., Li, C., Liu, Z., Qi, L., Tan, Y., Cheng, Y., Deng, C., Qiao, Y., 2014. Pronounced changes in atmospheric circulation and dust source area during the mid-Pleistocene as indicated by the Caotan loess-soil sequence in North China. Quat. Int. http://dx.doi.org/10.1016/j.quaint.2014.09.075.

Porter, S.C., 2001. Chinese loess record of monsoon climate during the last glacial-interglacial cycle. Earth Sci. Rev. 54, 115-128.

Pullen, A., Kapp, P., McCallister, A.T., Chang, H., Gehrels, G.E., Garzione, C.N. Heermance, R.V., Ding, L., 2011. Qaidam Basin and northern Tibetan Plateau as dust sources for the Chinese Loess Plateau and paleoclimatic implications. Geology 39, 1031-1034.

Pye, K., 1995. The nature, origin and accumulation of loess. Quat. Sci. Rev. 14, 653-667.

Pye, K., 1987. Eolian Dust and Dust Deposits. Academic Press, London, p. 334.
Qian, W., Quan, L., Shi, S., 2002. Variations of the dust storms in China and its climatic control. J. Clim. 15, 1216-1229.

Stevens, T., Adamiec, G., Bird, A.F., Lu, H., 2013a. An abrupt shift in dust source on the Chinese Loess Plateau revealed through high sampling resolution OSL dating. Quat. Sci. Rev. 82, 121-132.

Stevens, T., Carter, A., Watson, T.P., Vermeesch, P., Andò, S., Bird, A.F., Lu, H., Garzanti, E., Cottam, M.A., Sevastjanova, I., 2013b. Genetic linkage between the Yellow River, the Mu Us desert and the Chinese Loess Plateau. Quat. Sci. Rev. 78, 355-368.

Sun, J., 2002. Provenance of loess material and formation of loess deposits on the Chinese Loess Plateau. Earth Planet. Sci. Lett. 203, 845-859.

Sun, J., 2005. Nd and Sr isotopic variations in Chinese eolian deposits during the past 8 Ma: implications for provenance change. Earth Planet. Sci. Lett. 240, $454-466$.

Sun, J., Liu, T., Lei, Z., 2000. Sources of heavy dust fall in Beijing, China on April 16, 1998. Geophys. Res. Lett. 27, 2105-2108.

Sun, J., Zhang, M., Liu, T., 2001. Spatial and temporal characteristics of dust storms in China and its surrounding regions, 1960-1999: relations to source area and climate. J. Geophys. Res. 106 (D10), 10325-10333.

Sun, Y., Tada, R., Chen, J., Liu, Q., Toyoda, S., Tani, A., Ji, J., Isozaki, Y., 2008. Tracing the provenance of fine-grained dust deposited on the central Chinese Loess Plateau. Geophys. Res. Lett. 35, L01804. http://dx.doi.org/10.1029/2007GL031672.

Torii, M., Lee, T.Q., Fukuma, K., Mishima, T., Yamazaki, T., Oda, H., Ishikawa, N., 2001. Mineral magnetic study of the Taklimakan desert sands and its relevance to the Chinese loess. Geophys. J. Int. 146, 416-424.

Vriend, M., Prins, M.A., Buylaert, J.P., Vandenberghe, J., Lu, H., 2011. Contrasting dust supply patterns across the north-western Chinese Loess Plateau during the last glacial-interglacial cycle. Quat. Int. 240, 167-180.

Wang, B., Xia, D., Yu, Y., Jia, J., Xu, S., 2013. Magnetic records of heavy metal pollution in urban topsoil in Lanzhou, China. Chin. Sci. Bull. 58, 384-395. http:// dx.doi.org/10.1007/s11434-012-5404-8.

Wang, G., Oldfield, F., Xia, D., Chen, F., Liu, X., Zhang, W., 2012. Magnetic properties and correlation with heavy metals in urban street dust: a case study from the city of Lanzhou, China. Atmos. Environ. 46, 289-298.

Wang, X., Dong, Z., Yan, P., Yang, Z., Hu, Z., 2005. Surface sample collection and dust source analysis in northwestern China. CATENA 59, 35-53.

Wang, X., Dong, Z., Zhang, J., Liu, L., 2004. Modern dust storms in China: an overview. J. Arid Environ. 58, 559-574.

Wang, X., Xia, D., Wang, T., Xue, X., Li, J., 2008. Dust sources in arid and semiarid China and southern Mongolia: impacts of geomorphological setting and surface materials. Geomorphology 97, 583-600.

Wang, X., Zhou, Z., Dong, Z., 2006. Control of dust emissions by geomorphic conditions, wind environments and land use in northern China: an examination based on dust storm frequency from 1960 to 2003. Geomorphology 81, $292-308$

Wang, X., Dong, Z., Zhang, C., Qian, G., Luo, W., 2009. Characterization of the composition of dust fallout and identification of dust sources in arid and semiarid North China. Geomorphology 112, 144-157.

Wimpenny, J., Yin, Q., Tollstrup, D., Xie, L., Sun, J., 2014. Using Mg isotope ratios to trace Cenozoic weathering changes: a case study from the Chinese Loess Plateau. Chem. Geol. 376, 31-43.

Wu, G., Xu, B., Zhang, C., Gao, S., Yao, T., 2009. Geochemistry of dust aerosol over the Eastern Pamirs. Geochim. Cosmochim. Acta 73, 977-989.

Xiao, Z., Shao, L., Zhang, N., Wang, J., Chuang, H., Deng, Z., Wang, Z., BéruBé, K., 2014 A toxicological study of inhalable particulates in an industrial region of Lanzhou City, northwestern China: results from plasmid scission assay. Aeolian Res. 14, $25-34$.

Xiao, Z., Shao, L., Zhang, N., Li, W., 2010. Composition variation of PM10 during a dust storm episode in Lanzhou, northwestern China. J. Liaoning Tech. Univ. 29, 506-508 (in Chinese).

Xiao, Z., Shao, L., Zhang, N., Wang, J., Wang, J., 2013. Heavy metal compositions and bioreactivity of airborne PM10 in a valley-shaped city in northwestern China. Aerosol Air Qual. Res. 13, 1116-1125.

Yang, X., Liu, Y., Li, C., Song, Y., Zhu, H., Jin, X., 2007. Rare earth elements of aeolian deposits in Northern China and their implications for determining the provenance of dust storms in Beijing. Geomorphology 87, 365-377.

Zhang, H., Lu, H., Jiang, S., Vandenberghe, J., Wang, S., Cosgrove, R., 2012. Provenance of loess deposits in the Eastern Qinling Mountains (central China) and their implications for the paleoenvironment. Quat. Sci. Rev. 43, 94-102.

Zhang, Z., Sun, Y., Li, G., Liu, Q., 2011. PIXE analysis of heavy metal elements in total suspended particulates of Lanzhou in winter. Nucl. Tech. 34, 70-75 (in Chinese),

Zhou, Z, Zhang G, 2003. Typical severe dust storms in northern China during 1954-2002. Chin. Sci. Bull. 48, 2366-2370. 